\title{
One-pot hydrothermal synthesis and characterization of magnetic nanocomposite of titania-deposited copper ferrite/ferrite oxide for photocatalytic decomposition of methylene blue dye
}

\author{
Zahra Nasrollahi $^{1}$ (D) Azadeh Ebrahimian Pirbazari ${ }^{2}$ D $\cdot$ Atefeh Hasan-Zadeh $^{3} \mathbb{D} \cdot$ Ali Salehi $^{4}$
}

Received: 19 September 2019 / Accepted: 28 October 2019 / Published online: 6 November 2019

(c) The Author(s) 2019

\begin{abstract}
The pure titania $\left(\mathrm{TiO}_{2}\right)$ and the heterogeneous ternary magnetic nanocomposite of copper ferrite/ferrite oxide $\left(\mathrm{CuFe}_{2} \mathrm{O}_{4} /\right.$ $\mathrm{Fe}_{2} \mathrm{O}_{3}$ ) deposited by titanium dioxide $\left(\mathrm{TiO}_{2}\right)$ were fabricated using a facile one-pot hydrothermal synthesis for the photocatalytic decomposition of methylene blue (MB) dye, under visible light. The nanocomposite was encoded as TCF in this work, where $\mathrm{T}$ stands for $\mathrm{TiO}_{2}, \mathrm{C}$ for $\mathrm{CuFe}_{2} \mathrm{O}_{4}$ and $\mathrm{F}$ for $\mathrm{Fe}_{2} \mathrm{O}_{3}$. Various techniques such as powder X-ray diffraction (PXRD), field emission scanning electron microscopy (FESEM), energy-dispersive X-ray spectroscopy, diffuse reflectance spectroscopy, nitrogen physisorption, and vibrational sample magnetometry (VSM) were used to characterize the prepared samples. The PXRD data showed that the samples had pure anatase structure and the average crystal size of anatase $\mathrm{TiO}_{2}$ in the pure titania and ternary nanocomposite were calculated $147 \AA$ and $135 \AA$, respectively. The nitrogen physisorption analysis data showed that the pore diameter was increased from $10.6 \mathrm{~nm}$ in pure titania to $16.0 \mathrm{~nm}$ in TCF. The pore volume was also increased from 0.316 in titania to $0.383 \mathrm{~cm}^{3} / \mathrm{g}$ in TCF sample. It also increased the typical magnitude of the mesopores' diameter and volume per weight but it reduced the specific surface area of the samples. The VSM analysis of the ternary nanocomposite showed a considerable magnetic property of the sample $(1.99 \mathrm{emu} / \mathrm{g})$, qualifying it as a paramagnetic material. The photocatalytic decomposition efficiency of MB reached $77 \%$ and $68 \%$ in the presence of pure titania and TCF ternary nanocomposite, after 240-min exposure by the visible light. Active species trapping experiments showed that the major active species responsible for the photodecomposition of MB in the presence of TCF are $\mathrm{O}_{2}^{--}$radicals and holes $\left(\mathrm{h}^{+}\right)$.
\end{abstract}

Keywords Titania $\cdot$ Copper ferrite $\cdot$ Ferrite oxide $\cdot$ Photocatalytic decomposition $\cdot$ Methylene blue

\section{Introduction}

Increasing human population and industrial development have led to the release of various kinds of pollutants into the environment. Clean water is one of the vital elements of life, so the elimination of pollutants including organic

Zahra Nasrollahi

z.nasr@ut.ac.ir

1 Nano-physics, Fouman Faculty of Engineering, College of Engineering, University of Tehran, 1st Kilometer of Masouleh Road, Fouman, Guilan 43581-39115, Iran

2 Analytical Chemistry, Fouman Faculty of Engineering, College of Engineering, University of Tehran, Fouman, Guilan, Iran

3 Mathematics, Fouman Faculty of Engineering, College of Engineering, University of Tehran, Fouman, Guilan, Iran

4 Chemical Engineering, Fouman Faculty of Engineering, College of Engineering, University of Tehran, Fouman, Guilan, Iran contaminations such as pharmaceutical by-products, agrochemicals, dyes, paper, rubber, plastic, etc. from ground and wastewater has become one of the most important challenges for all countries [1].

In general, effluent water comprises about $10-200 \mathrm{mg} / \mathrm{L}$ of dyes and other chemicals utilized in dyeing procedures. Dyes are toxic and they resist natural deterioration. Furthermore, they scatter the sunlight passing through the water and consequently prevent the photosynthesis process in aquatic plants [2, 3].

Methylene blue dye (MB) is a well-known organic dye polluting wastewater. $\mathrm{MB}$ is the photocatalytic reactant 
prototype in this research. It has an aromatic heterocyclic chemical structure with the $\mathrm{C}_{16} \mathrm{H}_{18} \mathrm{ClN}_{3} \mathrm{~S}$ formula shown in Fig. 1 [4], and it is one of the cationic water-soluble dyes. It is a dark green and odorless powder that creates a blue solution when mixed with water. Because of various advantages such as low price, high color intensity and brightness, it is one of the common pigments used in the textile and dyeing industries [5]. On the other hand, the usual side effects caused by exposure to the MB-tainted wastewater are dizziness, headache, increased sweating, nausea, confusion, vomiting, shortness of breath, and high blood pressure. The other effects include mild bladder irritation, abdominal pain, diarrhea, upset stomach, frequent urination, stomach cramps, and hemolysis [6]. As a result, the removal of this chemical from effluent seems imperative.

Several approaches, such as biological treatment, membrane-based filtration, ion exchange, adsorption, precipitation, reverse osmosis, electrostatic captivation, and advanced oxidation processes (AOPs) such as photocatalytic decomposition, have been practiced [7, 8]. AOPs can decrease contamination content of water by several orders of magnitude, from hundreds of ppm (particles per million) to a few ppb (particles per billion); therefore, they reduce chemical oxygen demand (COD) and total oxygen demand (TOD) in aqueous environments. The COD is a parameter that indicates the amount of oxygen needed to chemically oxidize all constituent organic materials in the water sample. On the other hand, the biological or biochemical oxygen demand (BOD) shows the amount of oxygen needed to decompose organic compounds by wastewater bacteria. As a result, the parameter TOD that is the sum of COD and BOD, is considered as a standard reference parameter for the evaluation of wastewater organic pollution [9]. Among numerous techniques, photocatalytic decomposition is broadly used for water treatment because the procedure is a simple and low cost method of efficiently eliminating organic chemical compounds in aqueous phase, and it produces water and small inorganic by-products that are not environmentally hazardous [2, 3, 7, 9-11].
In addition, AOPs are based on in situ production of very reactive species such as hydroxyl radicals $\left(\mathrm{OH}^{\circ}\right)$ that can unselectively oxidize every compound mixed with water, and consequently, various chemical pollutants can be removed simultaneously. The hydroxyl radicals can be produced in the presence of energy sources (e.g., UV radiation), oxidizing agents (e.g., hydrogen peroxide, ozone, and oxygen), and catalysts (e.g., titanium dioxide) $[9,12-16]$.

Due to its environmental stability and safety, titanium dioxide $\left(\mathrm{TiO}_{2}\right)$ has appeared as a promising heterogeneous photocatalyst under UV beam, as it has a large bandgap energy of around 3.0-3.3 eV. Ultraviolet irradiation can excite and transfer electrons from the valence band to the conduction band and consequently increase of $\mathrm{TiO}_{2}$ photocatalytic activity. However, only $5 \%$ of the solar spectrum lies within the UV range, and a significant part of it is in the visible and infrared frequency domain. Furthermore, via the catalytic photoexcitation, $\mathrm{TiO}_{2}$ shows a high electron-hole pair $\left(\mathrm{e}^{-} / \mathrm{h}^{+}\right)$recombination rate that leads to a low photocatalytic efficiency. To overcome these issues, different methods have been applied to $\mathrm{TiO}_{2}$ such as metal or nonmetal doping, surface sensitizing, and combination with low bandgap semiconductors [17-20].

Recently, magnetic nanoparticles have been widely used for water treatment [21-25]. Due to their very small size and large surface-to-volume ratio, they have a high elimination capacity, fast kinetics and significant reactivity towards pollutants removal. More importantly, improvement of the magnetic properties of the catalyst is a useful characteristic, aiding in its separation from water after the contamination decomposition. It is expected that magnetic separation would be cheaper and more appropriate compared to membrane filtration [7, 26, 27].

Nanoparticles of spinel ferrite have the general formula of $\left[\mathrm{A}^{+2}\right]\left[\mathrm{Fe}^{+3}\right]_{2} \mathrm{O}_{4}$, where $\mathrm{A}$ is a divalent cationic metal like nickel (Ni), Mn, or copper (Cu). Structural, electrical, magnetic, and catalytic properties of spinel ferrite depend on the constituent atoms and their distribution in the A metal and iron sites. Reducing the size of magnetic nanoparticles

Fig. 1 Methylene blue chemical structure. On the left side 2D, and on the right side 3D images are shown. The pictures were drawn using the online tool at reference [4]
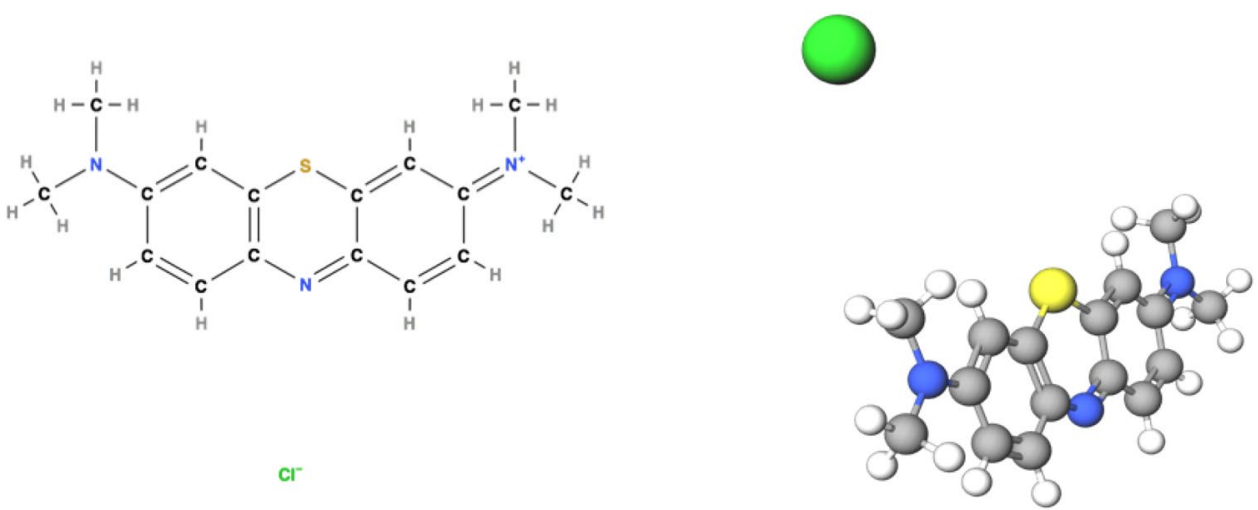
enhances the number of surface atoms that gives rise to the improvement of catalyst magnetic property. Spinel copper ferrite $\left(\mathrm{CuFe}_{2} \mathrm{O}_{4}\right)$ is one of the heterogeneous groups of magnetic nanophotocatalysts that have hydroxyl groups, chemical and thermal stability, non-carcinogenicity, low bandgap energy, and magnetic properties that cause easy separation from water [28].

Metal oxides such as $\mathrm{Fe}_{2} \mathrm{O}_{3}$ can electronically modify the photocatalysts and have a dramatic effect on the reactivity of the system. The electron-hole separation and the electron transfer at the interface can be significantly affected by metal oxide modification $[29,30]$. The application of super-paramagnetic $\mathrm{Fe}_{2} \mathrm{O}_{3}$ nanoparticles as photocatalysts for organic dye decomposition in wastewater looks very encouraging, due to their large surface area leading to large loading capacity, significant stability, cost-effective provision, and ecofriendly properties [31]. In addition, a highlighted benefit of using iron oxide is their magnetic properties that make their separation from water much easier compared to other methods, because they are attracted towards the externally applied magnetic field [32].

There have been few reports on the synthesis of $\mathrm{TiO}_{2} /$ $\mathrm{CuFe}_{2} \mathrm{O}_{4}$ used for photocatalytic applications [33-36]. In this work, the magnetic recyclable catalyst, $\mathrm{TiO}_{2} / \mathrm{CuFe}_{2} \mathrm{O}_{4} /$ $\mathrm{Fe}_{2} \mathrm{O}_{3}$ (TCF), was prepared using the one-pot hydrothermal method. The prepared samples, pure titania and TCF, were characterized by different analyses such as powder $\mathrm{X}$-ray diffraction (PXRD), field emission scanning electron microscopy (FESEM), energy-dispersive X-ray spectroscopy (EDX), diffuse reflectance spectroscopy (DRS), nitrogen physisorption, and vibrational sample magnetometry (VSM). The samples were then used for photocatalytic decomposition of MB.

\section{Experimental details}

\section{Chemicals}

Chemical materials used for the experiments were of analytical grade and mostly acquired from Merck Company (Germany). They included: titanium tetra isopropoxide $\left(\mathrm{Ti}\left(\mathrm{OCH}\left(\mathrm{CH}_{3}\right)_{2}\right)_{4}\right.$ or TIP; Merck No. 821895) and MB $\left(\mathrm{C}_{16} \mathrm{H}_{18} \mathrm{ClN}_{3} \mathrm{~S}\right.$ or MB; Merck, No. 115943). Other materials that were consumed for photocatalytic synthesis consisted of ethanol $\left(\mathrm{C}_{2} \mathrm{H}_{5} \mathrm{OH}\right.$, Merck No. 818760), acetylacetone $\left(\mathrm{C}_{5} \mathrm{H}_{8} \mathrm{O}_{2}\right)$, copper chloride $\left(\mathrm{CuCl}_{2} \cdot 2 \mathrm{H}_{2} \mathrm{O}\right)$ and ferric chloride $\left(\mathrm{FeCl}_{3} \cdot 6 \mathrm{H}_{2} \mathrm{O}\right)$, sodium hydroxide $(\mathrm{NaOH})$, and deionized water. Triethanolamine (or trolamine, $\mathrm{C}_{6} \mathrm{H}_{15} \mathrm{NO}_{3}$, Merck No. 108372), isopropyl alcohol $\left(\mathrm{C}_{3} \mathrm{H}_{8} \mathrm{O}\right.$, Merck No. 100995) and ascorbic acid $\left(\mathrm{C}_{6} \mathrm{H}_{8} \mathrm{O}_{6}\right)$ were used as active species scavengers. All the reagents were applied as purchased without additional purification.

\section{Photocatalyst synthesis}

A pure $\mathrm{TiO}_{2}$ sample was synthesized through a hydrothermal method used by Ebrahimian et al. [37]. The magnetic nanoparticles of $\mathrm{CuFe}_{2} \mathrm{O}_{4}$ were prepared according to the method reported by Hashemian et al. [38], and then they were calcinated at $700{ }^{\circ} \mathrm{C}$ for $5 \mathrm{~h}$ in air atmosphere. To prepare TCF, a $250-\mathrm{mL}$ glass beaker was filled with $20 \mathrm{~mL}$ of TIP, $20 \mathrm{~mL}$ of ethanol, $1.6 \mathrm{~mL}$ of acetone and blended for $30 \mathrm{~min}$ in an ambient condition. Afterwards, another solution consisting of $0.5 \mathrm{~g}$ of the prepared $\mathrm{CuFe}_{2} \mathrm{O}_{4}, 80 \mathrm{~mL}$ of ethanol, and $2 \mathrm{~mL}$ of deionized $\mathrm{H}_{2} \mathrm{O}$ was poured into the first solution, yielding a grayish white solution. The resultant solution was poured into an autoclave, heated up to $220{ }^{\circ} \mathrm{C}\left(3{ }^{\circ} \mathrm{C} / \mathrm{min}\right)$, and kept at this temperature for $6 \mathrm{~h}$. Then, it was cooled down to room temperature gradually, washed by ethanol and water and then dried at $80^{\circ} \mathrm{C}$ for another $6 \mathrm{~h}$ in air atmosphere. The final brown TCF nanocomposite was ground by a mortar to be used for the photodecomposition process.

\section{Characterization}

The diffraction patterns were recorded using a Siemens D5000 (Germany), with $\mathrm{Cu}-\mathrm{K}_{\alpha}(\lambda=1.54 \AA)$ as the X-ray radiation source, in a $2 \theta$ range of $20^{\circ}-70^{\circ}$. The chemical, structural and topographical characteristics of the samples were characterized by FESEM TESCAN MIRA3, complemented by an EDX analyzer. To compute the bandgap energy of the materials, the diffused reflectance spectroscopy (DRS) was carried out by a UV-Vis Scinco 4100 spectrometer in the range of 330-950 nm.

The nitrogen physisorption was measured using a BELSORP-mini II. After outgassing the instrument at $250{ }^{\circ} \mathrm{C}$, the pressure was decreased to less than $5 \mathrm{~m}$ bars. Subsequently, the Brunauer-Emmett-Teller (BET) areas were determined by measuring static nitrogen physisorption at the temperature of $-196{ }^{\circ} \mathrm{C}$. Furthermore, the magnetic properties of $\mathrm{CuFe}_{2} \mathrm{O}_{4}$ and TCF were measured using a vibrating sample magnetometer (VSM) system (Meghnatis Daghighe Kavir Kashan LBKF, Iran) in the maximum magnetic field intensity of $1 \mathrm{~T}$.

\section{Photocatalytic decomposition of MB}

The decomposition of MB was followed by measuring the solution absorbance $(A)$ at the maximum absorption wavelength of $\mathrm{MB}$ dye $\left(\lambda_{\max }=665 \mathrm{~nm}\right)$ at 30 -min intervals. UV-Vis spectra were recorded on a double beam UV-visible spectrophotometer (Rayleigh UV-2601). Before exposure to irradiation, a suspension containing different amounts of the photocatalyst $(0.05-0.3 \mathrm{~g})$ and $100 \mathrm{~mL}$ of MB aqueous solution (10 ppm) was stirred continuously for $60 \mathrm{~min}$ in the dark to reach the adsorption/desorption equilibrium. 
Then the sample, under magnetic stirring, was illuminated by four UVA lamps (Kr lamp, $500 \mathrm{~W}$, Osram, Germany, $\left.\lambda_{\max }=360 \mathrm{~nm}\right)$ or a tungsten lamp $(500 \mathrm{~W}$, Halogen, ECO Osram), positioned at $100 \mathrm{~cm}$ above the glass beaker. To measure the decline of the MB concentration, a sample of $2 \mathrm{~mL}$ was taken with a pipette at prespecified time intervals and centrifuged at $4000 \mathrm{rpm}$. The percentage of MB decomposition was obtained via Eq. (1):

$\%$ Decomposition efficiency $=\frac{\left(C_{0}-C_{t}\right)}{C_{0}} \times 100$,

where $C_{0}$ and $C_{t}(\mathrm{mg} / \mathrm{L})$ are the initial concentration and the concentration of MB at time $t$, respectively.

\section{Results and discussion}

\section{PXRD analysis}

The PXRD patterns of the samples were recorded in the $2 \theta=20^{\circ}$ to $70^{\circ}$ range with $0.02^{\circ}$ scan intervals, and the results are shown in Fig. 2.

Figure 2A exhibits the PXRD patterns of $\mathrm{CuFe}_{2} \mathrm{O}_{4}$ before (a) and after (b) calcination. The pre-calcination pattern indicates that the sample has an amorphous structure, while after calcination the pattern of the sample shows diffraction at $2 \theta=30.00^{\circ}, 34.66^{\circ}, 36.02^{\circ}, 44.57^{\circ}, 58.16^{\circ}, 62.42^{\circ}$, and $64.02^{\circ}$ attributed to (112), (103), (211), (320), (303), (321), and (224) crystalline planes. This result is consistent with previous reports [39] and indicates that tetragonal copper spinel crystals have been formed. In addition to characteristic diffractions of $\mathrm{CuFe}_{2} \mathrm{O}_{4}$, the diffractions that emerged at $2 \theta=33.5^{\circ}, 49.50^{\circ}$ and $54.5^{\circ}$ reveal that in addition to $\mathrm{CuFe}_{2} \mathrm{O}_{4}$, ferrite oxide $\left(\mathrm{Fe}_{2} \mathrm{O}_{3}\right)$ nanoparticles have probably been formed during the calcination of the sample at $700{ }^{\circ} \mathrm{C}$, and these diffraction angles correspond to the (104), (024), and (116) planar Miller indices [40-42].

In Fig. 2B (a), the PXRD pattern of the pure $\mathrm{TiO}_{2}$ sample reveals the diffractions at $2 \theta=25.46^{\circ}, 38.00^{\circ}, 48.16^{\circ}$, $54.12^{\circ}, 55.26^{\circ}$, and $62.92^{\circ}$ corresponding to the crystalline planes with Miller indices of (101), (004), (200), (105), (211), and (204), verifying the anatase crystalline structure of $\mathrm{TiO}_{2}$ nanoparticles (JCPDS-21-1272) [43].

Figure 2B (b) shows the PXRD pattern of the TCF sample with no indication of $\mathrm{CuFe}_{2} \mathrm{O}_{4}$ or $\mathrm{Fe}_{2} \mathrm{O}_{3}$ patterns. This can be due to the weight of $\mathrm{CuFe}_{2} \mathrm{O}_{4}$ and $\mathrm{Fe}_{2} \mathrm{O}_{3}$ nanoparticles being a very small fraction of the weight of $\mathrm{TiO}_{2}$ nanoparticles, and as a result, not having a substantial effect in the diffraction pattern of $\mathrm{TiO}_{2}$. Other possible reasons are the excellent crystallinity of $\mathrm{TiO}_{2}$ and its probable formation around $\mathrm{CuFe}_{2} \mathrm{O}_{4}$ and $\mathrm{Fe}_{2} \mathrm{O}_{3}$ nanoparticles leading to the absence of ferrite compound features in PXRD patterns.
Fig. 2 A The PXRD patterns of $\mathrm{CuFe}_{2} \mathrm{O}_{4}$ (a) before and (b) after calcination, and $\mathbf{B}$ The PXRD patterns of (a) $\mathrm{TiO}_{2}$ and (b) TCF samples
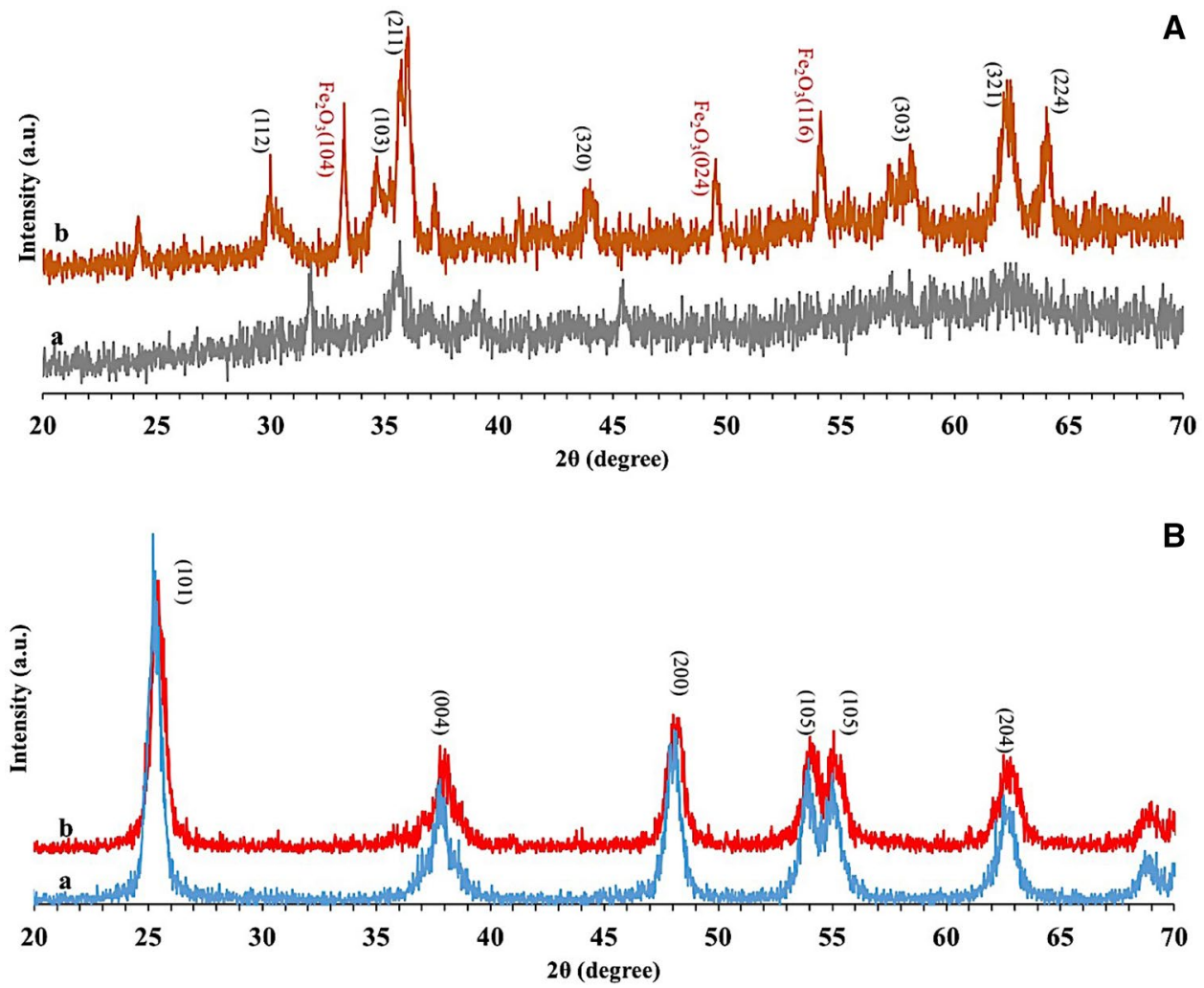
Furthermore, both patterns showed sharp peaks indicating high crystallinity of the samples, and the width of the peaks contains information about the sizes of the crystals as well.

According to the Scherrer equation, the $\mathrm{TiO}_{2}$ crystal size of each sample is related to the full width at half maximum of the diffraction:

$D_{h k l}=\frac{K \lambda}{\beta \cos (\theta)}$,

where $D_{h k l}$ is the average size of the particle and $h, k$ and $l$ are plane Miller indices, here equal to 1,0 , and $1 . K$ is a dimensionless, constant shape factor $(\sim 0.89), \lambda$ is the irradiated $\mathrm{X}$-ray wavelength $(0.1542 \mathrm{~nm}), 2 \theta$ is the angle between the scattered and the incident $\mathrm{X}$-ray plane wave vectors, corresponding to the maximum intensity of the diffraction, and finally, $\beta$ is the diffraction's full width (in radian) at its half maximum [44].

The results of the calculation in Table 1 show that the $\mathrm{TiO}_{2}$ crystals in both samples have nanoscale dimensions, and the crystal size of $\mathrm{TiO}_{2}$ in TCF sample is less than the crystal size in pure titania. The presence of $\mathrm{CuFe}_{2} \mathrm{O}_{4}$ and $\mathrm{Fe}_{2} \mathrm{O}_{3}$ nanoparticles may act as nucleation centers for the formation of $\mathrm{TiO}_{2}$ crystals, thus preventing the growth of $\mathrm{TiO}_{2}$ crystals during the hydrothermal synthesis.

Interplanar distance, $d_{h k l}$, can be determined using Bragg's equation [45]:

$2 d_{h k l} \sin (\theta)=n \lambda$,

where $n$ is a positive integer illustrating the reflection order and is assumed to be 1 The anatase phase of $\mathrm{TiO}_{2}$ has a tetragonal structure (lattice parameters: $a=b \neq c ; a, b$ and $c$ are the length, width, and height of the rectangular cuboid, respectively.), so $d_{h k l}$ is related to the lattice parameters by the following equation [46]:

$\frac{1}{d^{2}}=\frac{h^{2}+k^{2}}{a^{2}}+\frac{l^{2}}{c^{2}}$.

This equation was used to compute the lattice parameters and the cell volume $\left(V=a^{2} c\right)$ shown in Table 2 . To calculate $a$ and $c$ parameters, the third and first peaks at $2 \theta=30.0^{\circ}$ and $25.2^{\circ}$ corresponding to Miller indices of (200) and (101), respectively, were used. By comparison of the results of Table 1 with reported data [47-49], the anatase structure of titania is verified.
Table 2 Chemical composition of the samples from EDX analysis

\begin{tabular}{lllll}
\hline Sample & $\mathrm{Ti}(\mathrm{wt} \%)$ & $\mathrm{O}(\mathrm{wt} \%)$ & $\mathrm{Cu}(\mathrm{wt} \%)$ & $\mathrm{Fe}(\mathrm{wt} \%)$ \\
\hline $\mathrm{TiO}_{2}$ & 57.52 & 42.48 & - & - \\
$\mathrm{TCF}$ & 51.00 & 43.37 & 2.62 & 3.01 \\
\hline
\end{tabular}

\section{FESEM/EDX analyses}

FESEM images of the samples are shown in Fig. 3 with $100 \mathrm{~nm}$ and $1 \mu \mathrm{m}$ scales. The TCF sample shows minor accumulation compared to pure titania.

The EDX analysis was carried out to investigate chemical composition of the samples, and the results are shown in Fig. 4 and Table 2. Despite the PXRD patterns, the elemental analysis and EDX patterns confirmed the presence of Ti, $\mathrm{O}, \mathrm{Cu}$, and Fe. In Fig. 4A, two peaks are seen at 0.2, $4.5 \mathrm{keV}$, with the highest intensity observed at $4.5 \mathrm{keV}$. The stronger peak corresponds to the bulk titanium, and the weaker one is related to the surface titanium [48]. The peaks of copper are located at $0.7,8$ and $9 \mathrm{keV}$ [49], and iron $(\mathrm{Fe})$ peaks are seen at $0.9,6.1$ and $7 \mathrm{keV}$ [50].

The elemental mapping EDS images (Fig. 4B) exhibit the immensely and uniformly dispersed $\mathrm{CuFe}_{2} \mathrm{O}_{4}$ and $\mathrm{Fe}_{2} \mathrm{O}_{3}$ nanoparticles in the $\mathrm{TiO}_{2}$ host lattice. These images show the presence of $\mathrm{CuFe}_{2} \mathrm{O}_{4}$ and $\mathrm{Fe}_{2} \mathrm{O}_{3}$ in the composite structure, although in PXRD patterns, the analogous peaks of $\mathrm{CuFe}_{2} \mathrm{O}_{4}$ and $\mathrm{Fe}_{2} \mathrm{O}_{3}$ are not distinguishable. This illustrates the good interaction between $\mathrm{CuFe}_{2} \mathrm{O}_{4} / \mathrm{Fe}_{2} \mathrm{O}_{3}$ and $\mathrm{TiO}_{2}$ particles during the hydrothermal preparation method. Also, we can observe a wide range of particles in the TCF sample that greatly affect different parameters such as blocking temperature, magnetization, etc.

\section{DRS analysis}

The DRS analysis was used to determine what effects the combination of copper ferrite spinel/ferrite oxide with titanium dioxide could have on the bandgap energy $\left(E_{\mathrm{bg}}\right)$ of the photocatalyst. The results are shown in Fig. 5.

Figure 5A shows an intense broad absorption band around $400 \mathrm{~nm}$ corresponding to a charge transfer from $2 p$ orbitals of oxide onions valence band to $3 \mathrm{dt}_{2 \mathrm{~g}}$ orbitals of the $\mathrm{Ti}^{4+}$ cations $[49,51]$. The main absorption of $\mathrm{TiO}_{2}$ appears in the UV range due to its large $\mathrm{E}_{\mathrm{bg}}$. As can be

Table 1 Structural phase, crystal dimension, lattice parameters and band gap energies of the synthesized samples (calculated from DRS data using Kubelka-Munk function)

\begin{tabular}{lllllll}
\hline Sample & Phase & $a=b(\AA)$ & $c(\AA)$ & $V\left(\AA^{3}\right)$ & $D(\AA)$ & Band gap $(\mathrm{eV})$ \\
\hline $\mathrm{TiO}_{2}$ & Anatase & 3.8 & 9.8 & 140.3 & 147 & 2.99 \\
$\mathrm{TCF}$ & Anatase & 3.8 & 9.3 & 133.6 & 135 & 3.02 \\
\hline
\end{tabular}


Fig. 3 FESEM images of the samples with $1-\mu \mathrm{m}$ and $100-\mathrm{nm}$ scales: $\mathbf{a} \mathrm{TiO}_{2}$ and $\mathbf{b} \mathrm{TCF}$

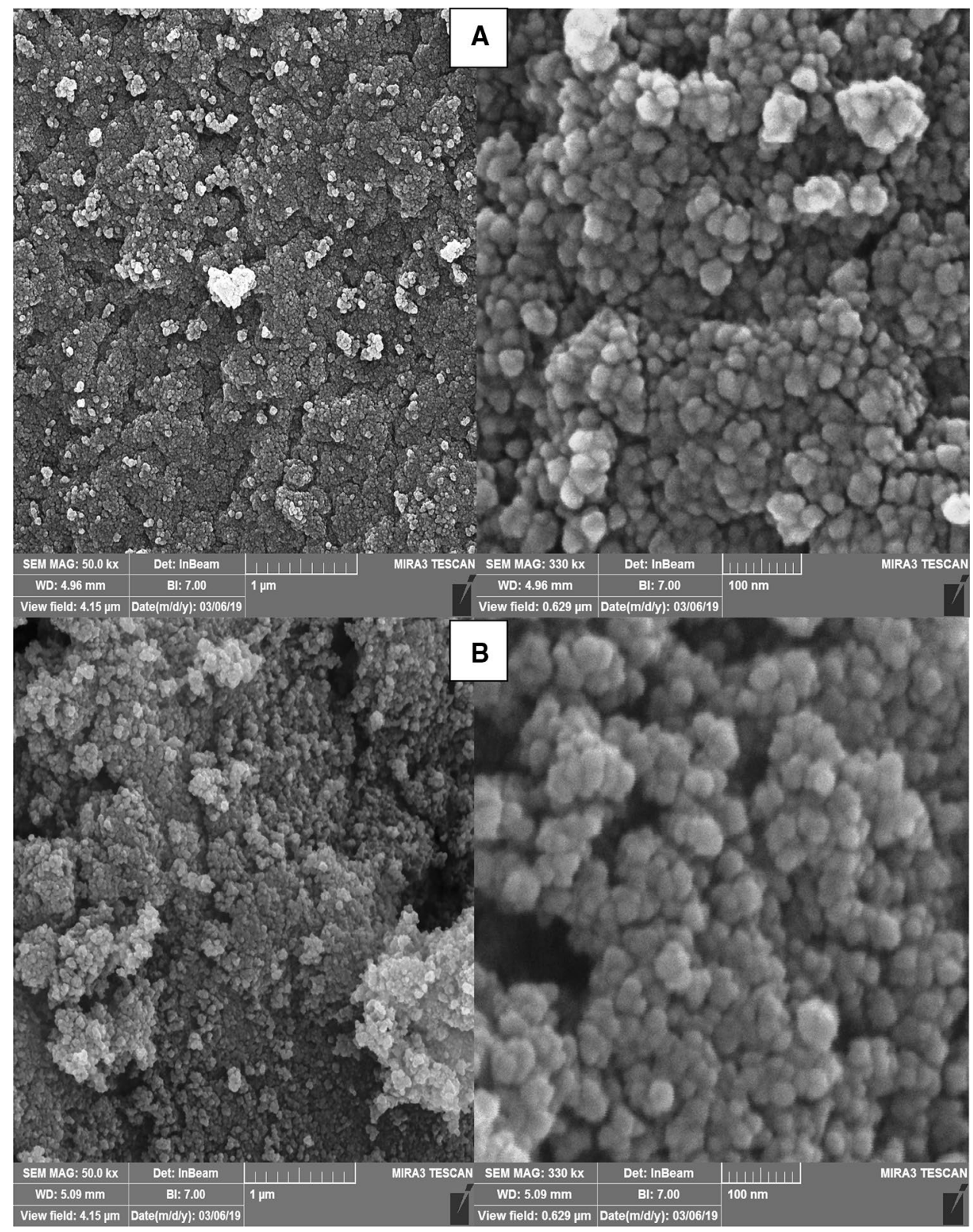

seen in the inset graph of Fig. 5A, there is a newly formed broad band from 450 to $630 \mathrm{~nm}$ that could be due to the presence of copper ferrite spinel/ferrite oxide in TCF.

The $E_{\mathrm{bg}}$ of the samples were calculated using Tauc's equation:

$(F(R) h v)^{0.5}=A\left(h v-E_{\mathrm{bg}}\right)$.

$F(R)$ is the Kubelka-Munk function, $\nu$ is the frequency acquired from the DRS spectra, $h$ is the Planck constant, and $A$ is another constant [52]. The results are summarized in Table 1 and Fig. 5B. The calculated $E_{\mathrm{bg}}$ of TCF (3.022 eV) does not show a remarkable change compared to the pure titania $E_{\mathrm{bg}}(2.991 \mathrm{eV})$, and this again confirms the formation of $\mathrm{TiO}_{2}$ around $\mathrm{CuFe}_{2} \mathrm{O}_{4} / \mathrm{Fe}_{2} \mathrm{O}_{3}$.

\section{Nitrogen physisorption}

Figure 6 shows the $\mathrm{N}_{2}$ physisorption isotherms and pore size distribution curves of the prepared samples. Both physisorption isotherms of the samples belong to Group IV of the International Union of Pure and Applied Chemistry (IUPAC) classification scheme. The samples' specific surface area and average pore size were calculated using the BET method, and the average pore volumes were computed 
Fig. 4 A EDX patterns of (a) $\mathrm{TiO}_{2}$ and (b) TCF, and $\mathbf{B}$ elemental mapping images of (a) $\mathrm{TiO}_{2}$ and (b) $\mathrm{TCF}$

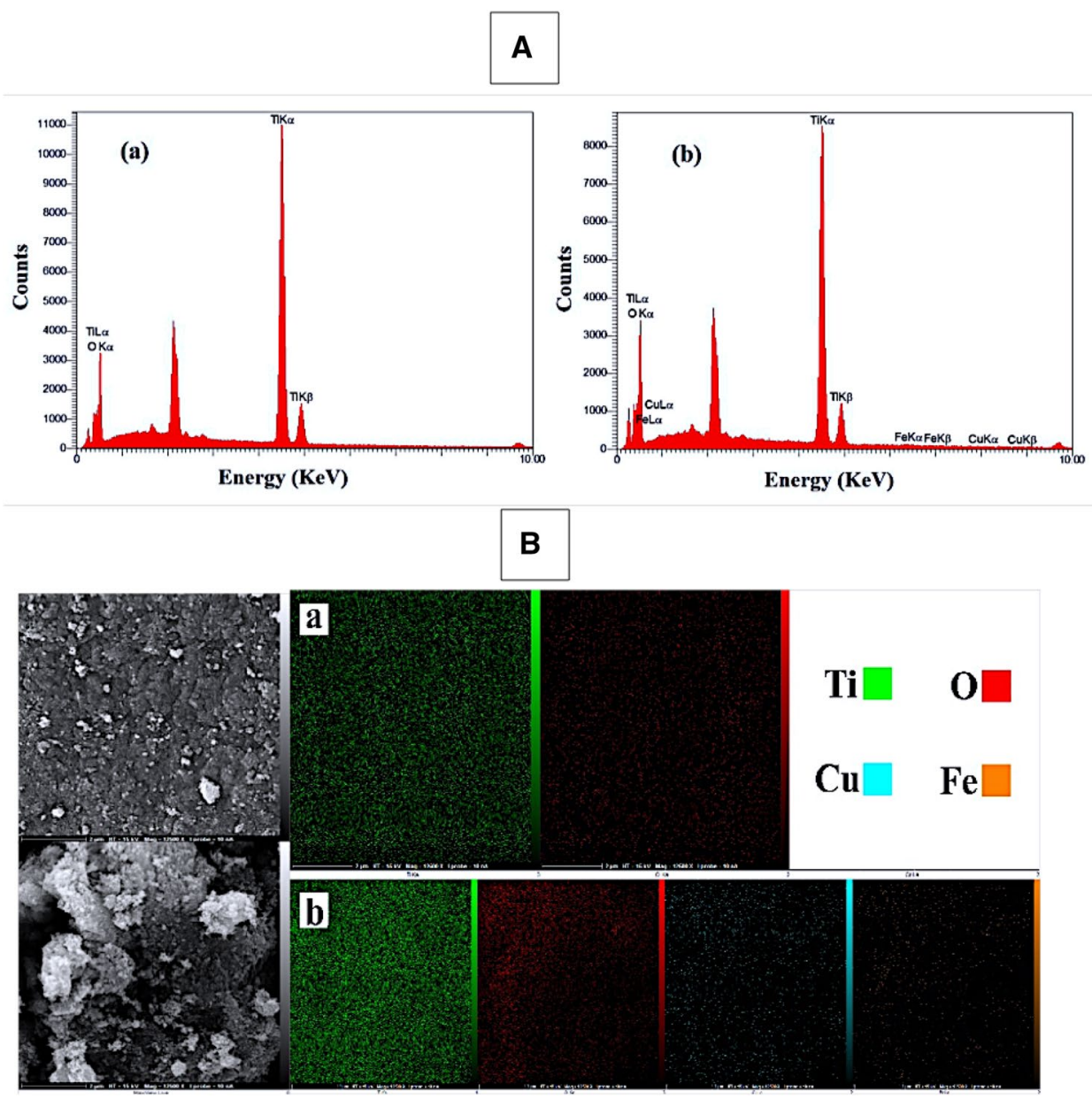

with the Barrett-Joyner-Halenda (BJH) model, using the adsorption branch data. The results are outlined in Table 3. According to IUPAC classification, materials with pore sizes between 2 and $50 \mathrm{~nm}$ are identified as mesoporous $[52,53]$. Based on the data shown in Table 3, both samples have mesopores in their structures. The nanocomposite particles have a larger average pore size, and as a result, they have less specific surface area. This could indicate that $\mathrm{TiO}_{2}$ has covered $\mathrm{CuFe}{ }_{2} \mathrm{O}_{4} / \mathrm{Fe}_{2} \mathrm{O}_{3}$ nanoparticle surface leading to the formation of ternary TCF compound [39]. Also, the presence of copper ferrite spinel/ferrite oxide gives rise to a significant increase in the pore volume per mass unit of the nanocomposite.

\section{VSM measurements}

The magnetization of $\mathrm{TiO}_{2}$ and $\mathrm{TCF}$ were measured using a VSM system at room temperature. The maximum external magnetic field intensity used to magnetize the materials was 1 Tesla. The hysteresis loops shown in Fig. 7 indicate a considerable magnetization value for $\mathrm{CuFe}_{2} \mathrm{O}_{4}(\sim 24.8 \mathrm{emu} / \mathrm{g})$. The ternary TCF nanocomposite exhibits about one order of magnitude less magnetization ( $1.99 \mathrm{emu} / \mathrm{g})$, which identifies it as a paramagnetic material. $\mathrm{TiO}_{2}$ particles cover the surface of $\mathrm{CuFe}_{2} \mathrm{O}_{4} / \mathrm{Fe}_{2} \mathrm{O}_{3}$ grains, leading to less magnetization compared to pure magnetic nanoparticles.

\section{Photocatalytic decomposition of MB}

To investigate the photodegradation efficiency of the synthesized samples, a suspension was prepared that consisted of different amounts of the photocatalyst in $100 \mathrm{~mL}$ of $\mathrm{MB}$ solution, with an initial concentration of $10 \mathrm{ppm}$ and $\mathrm{pH}$ 9. To reach the adsorption-desorption equilibrium state, the solution was stirred in the dark for $60 \mathrm{~min}$. Afterwards, it was exposed to tungsten light for $240 \mathrm{~min}$ or to UV irradiation.

Under UV radiation, pure titania showed 99\% removal in $60 \mathrm{~min}$, and TCF showed $98 \%$ removal in the same time period. However, under visible-light illumination, the situation was slightly different. The results for pure titania and TCF are shown in Fig. 8. For all the different amounts of samples in the suspension, the final decomposition for pure titania is a few percent more. This may be due to the smaller bandgap energy and large crystal size of pure titania compared to those of TCF samples (Table 1). 

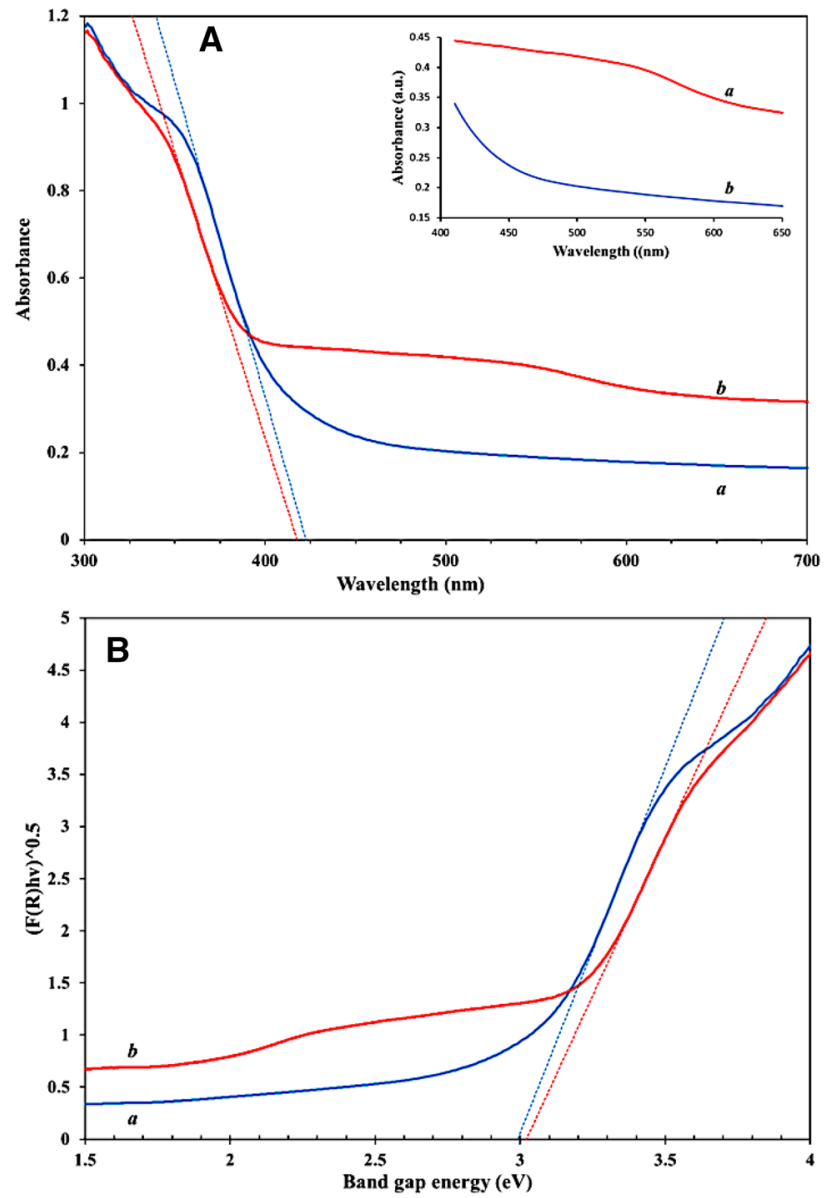

Fig. 5 A DR spectra vs wavelength (nm) for (a) $\mathrm{TiO}_{2}$ and (b) TCF; $\mathbf{B}$ Kubelka-Munk function of the samples vs energy band gap (eV) (a) $\mathrm{TiO}_{2}$ and (b) TCF

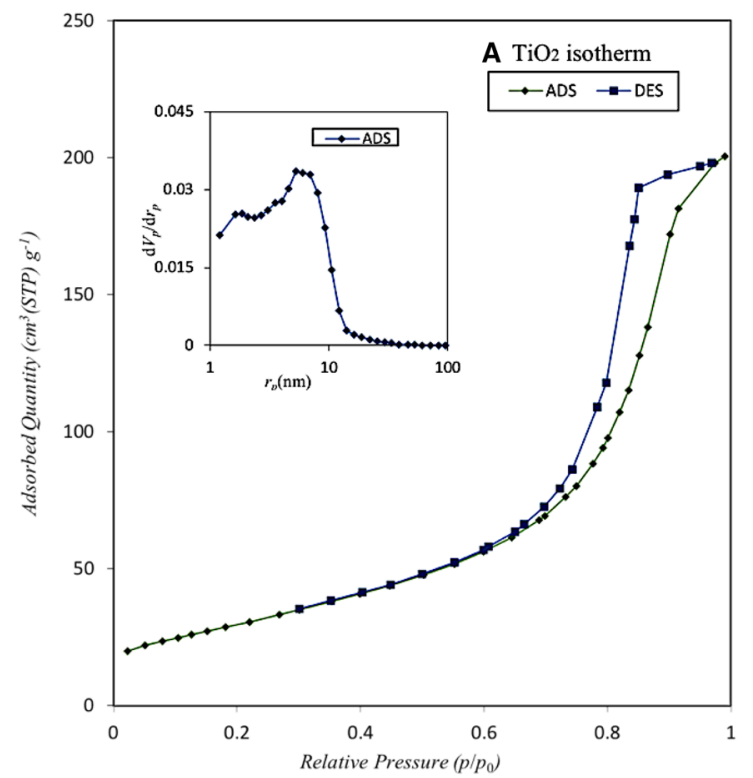

Table 3 Structural parameters of the synthesized samples

\begin{tabular}{llll}
\hline Sample & SBET $\left(\mathrm{m}^{2} / \mathrm{g}\right)$ & $\begin{array}{l}\text { Average pore diam- } \\
\text { eter }(\mathrm{nm})\end{array}$ & $\begin{array}{l}\text { Pore } \\
\text { volume } \\
\left(\mathrm{cm}^{3} / \mathrm{g}\right)\end{array}$ \\
\hline $\mathrm{TiO}_{2}$ & 110.0 & 10.6 & 0.316 \\
$\mathrm{TCF}$ & 102.3 & 16.0 & 0.383 \\
\hline
\end{tabular}

To find the major active species that are involved in the process of photodecomposition of $\mathrm{MB}$ in the presence of TCF samples, triethanolamine (TEOA), isopropanol (IPA), and ascorbic acid (AA) were employed as the scavengers of $\mathrm{h}^{+}, \mathrm{OH}$, and $\mathrm{O}_{2}^{--}$radicals, respectively. As shown in Fig. 9, the photocatalytic removal of MB was $60 \%$ without any scavenger material. The decomposition of MB in the presence of TEOA, IPA, and AA was $52 \%, 62 \%$, and $40 \%$, respectively. This indicates that $\mathrm{OH}^{\circ}$ does not play an appreciable role in the photodecomposition process, and the main species responsible for the decomposition of MB are $\mathrm{h}^{+}$and $\mathrm{O}_{2}^{--}$.

So the mechanism of MB decomposition can be suggested as below [29, 54, 55]:

$\mathrm{TCF}+h v \rightarrow \mathrm{TCF}\left(\mathrm{e}_{\mathrm{CB}}^{-}+\mathrm{h}_{\mathrm{VB}}^{+}\right)$,

$\mathrm{e}_{\mathrm{CB}}^{-}+\mathrm{O}_{2} \rightarrow \mathrm{O}_{2}^{--}$,

$\mathrm{h}_{\mathrm{VB}}^{+}+\mathrm{H}_{2} \mathrm{O} \rightarrow \mathrm{OH}^{-}+\mathrm{H}^{+}$,

$\mathrm{O}_{2}^{--}-\mathrm{H}^{+} \rightarrow \mathrm{HOO}^{-} \rightarrow \mathrm{OH}^{-}$

$\mathrm{h}^{+}+\mathrm{MB} \rightarrow$ decomposition products,

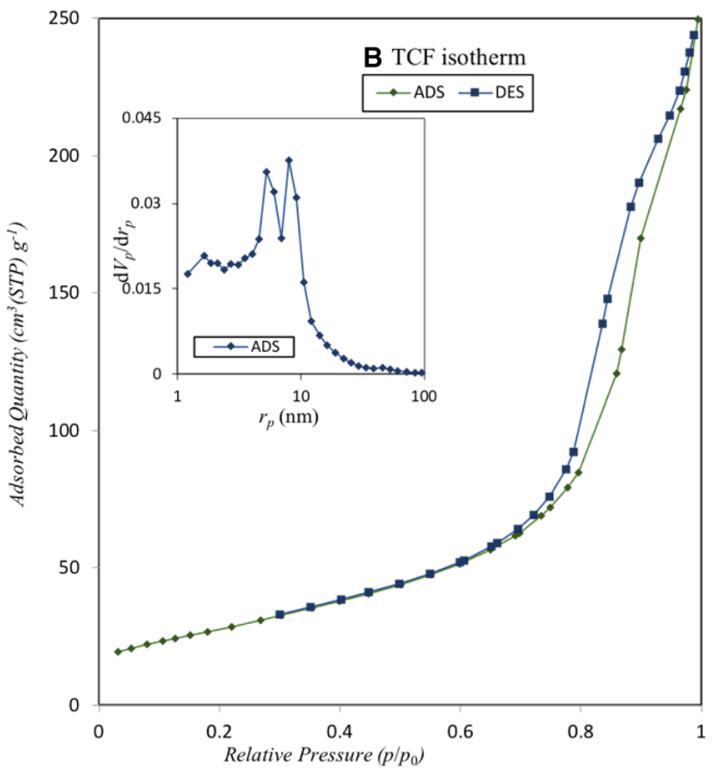

Fig. 6 Nitrogen physisorption isotherms of $\mathbf{a} \mathrm{TiO}_{2}$ and $\mathbf{b} \mathrm{TCF}$ samples. The inset graphs show the pore size distribution for each sample 
Fig. 7 Magnetization of a magnetic nanoparticles and $\mathbf{b}$ TCF sample vs external applied field

\section{Magnetic Nanoparticle}

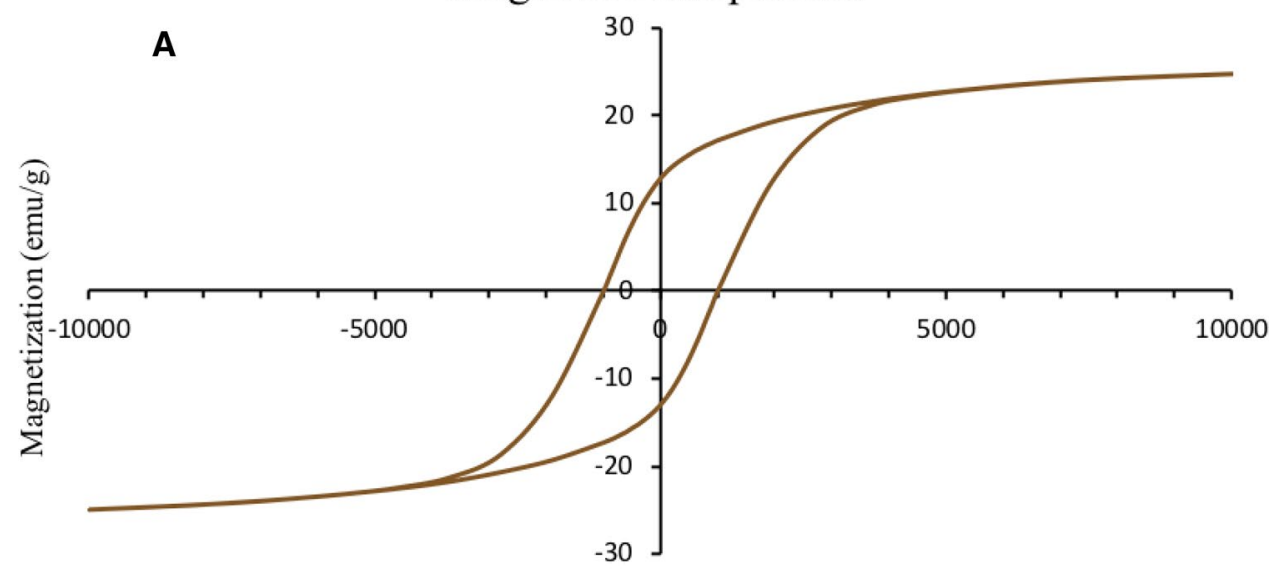

Applied Field (Oe)

\section{TCF}

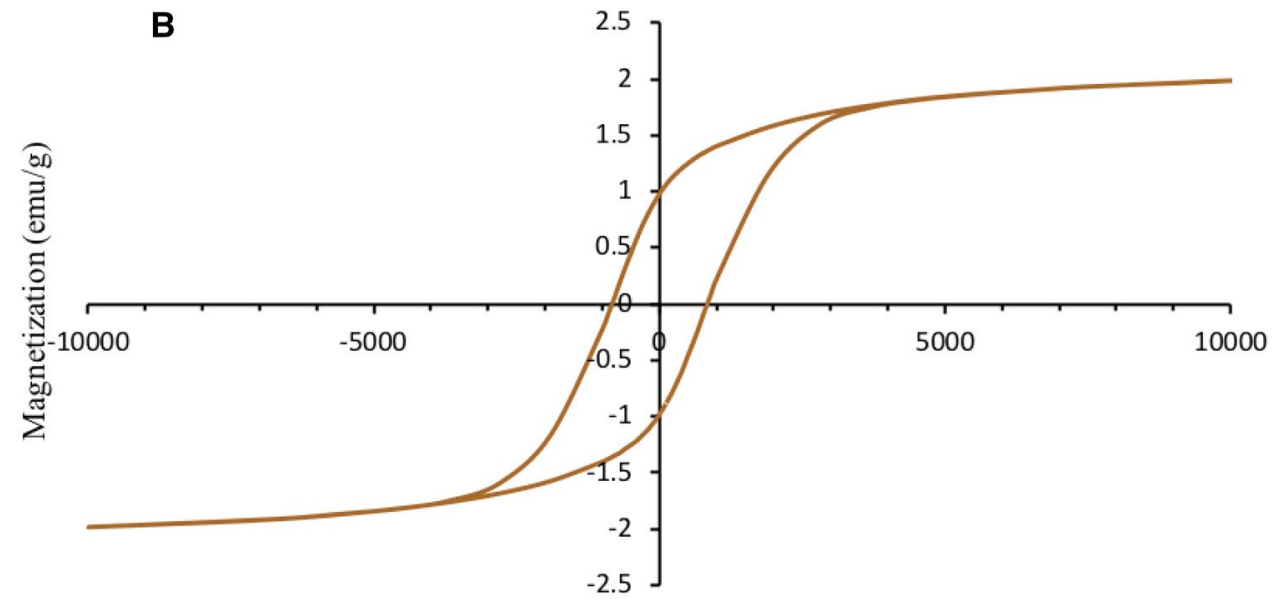

Applied Field (Oe)
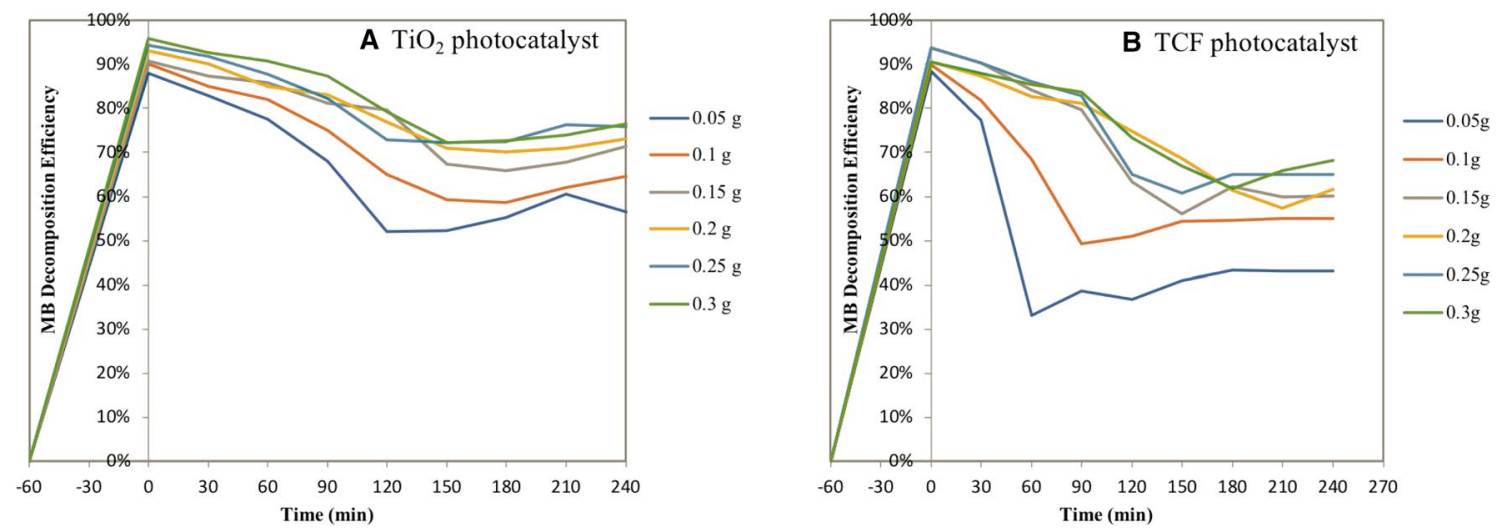

Fig. 8 Phtodecomposition efficiency of $\mathrm{MB}(10 \mathrm{ppm})$ in the presence of $\mathbf{a} \mathrm{TiO}_{2}$ photocatalyst and $\mathbf{b}$ TCF photocatalyst under the visible light for $240 \mathrm{~min}$ 

trapping experiments for TCF photocatalyst sample via difconcentration: $10 \mathrm{ppm}$; volume: $100 \mathrm{~mL}$; catalyst dosage: varying between 5 and $30 \mathrm{mg}$, illumination time: $240 \mathrm{~min}$ )
Fig. 9 The active species ferent scavengers (initial dye

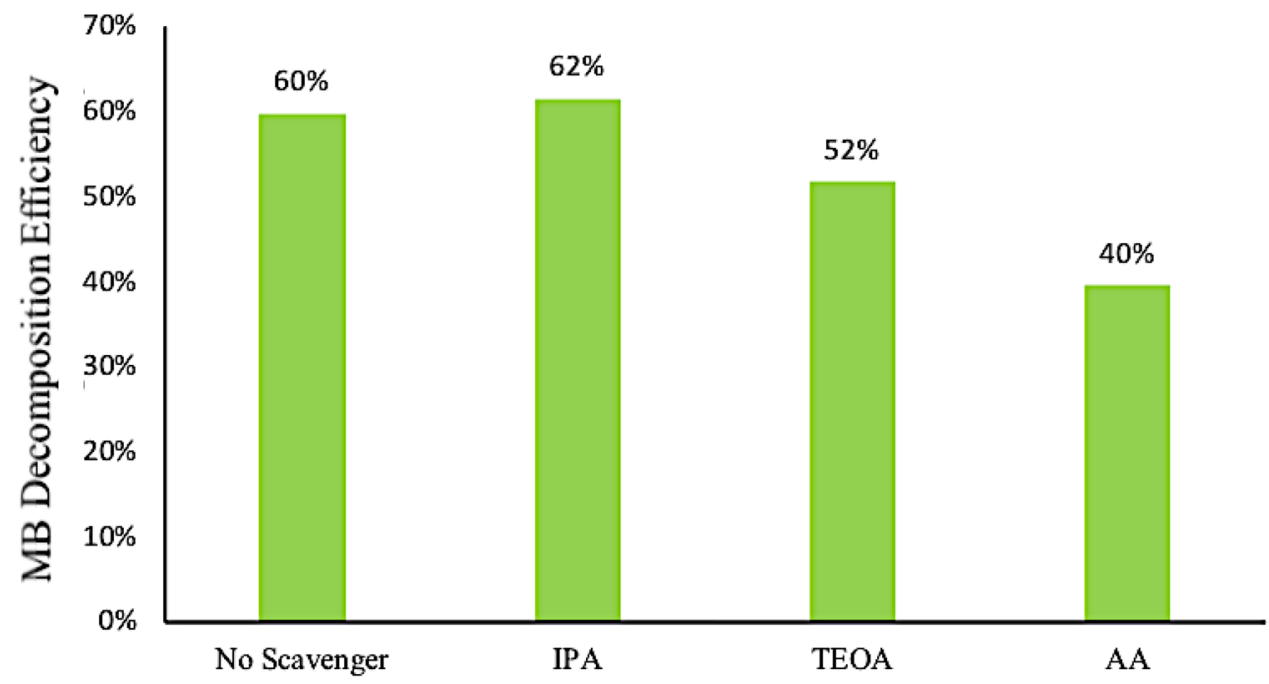

$\mathrm{OH}^{-}+\mathrm{MB} \rightarrow$ decomposition products.

\section{Conclusion}

Pure titania and magnetically reclaimable TCF nanocomposite were synthesized via a one-pot hydrothermal method and used for the visible-light photocatalytic decomposition of $\mathrm{MB}$, an organic dye found in wastewater from the textile industry. PXRD analysis indicated that both samples preserved their anatase phased structure, with the average crystal dimension of 13.1 and $14.7 \mathrm{~nm}$. The EDX and elemental mapping analyses confirm the presence of $\mathrm{CuFe}_{2} \mathrm{O}_{4} / \mathrm{Fe}_{2} \mathrm{O}_{3}$ in the TCF sample, although there is no sign of $\mathrm{CuFe}_{2} \mathrm{O}_{4}$ and $\mathrm{Fe}_{2} \mathrm{O}_{3}$ phases throughout the whole range investigated; so, we can confidently rule out the presence of any secondary phase within the limits of such detection by PXRD.

Adding $\mathrm{CuFe}_{2} \mathrm{O}_{4}$ to $\mathrm{TiO}_{2}$ did not change the bandgap energy; however, it increased the diameter and volume of the porous structure, which will lead to higher adsorption of pollutants in aqueous environments. In this work, pure titania showed about $10 \%$ more MB decomposition compared to the magnetic nanocomposite. The presence of TCF and $\mathrm{TiO}_{2}$, increased maximum decomposition of $\mathrm{MB}$ up to $68 \%$ and $77 \%$, respectively. The critical active species that are involved in photocatalytic decomposition of TCF are $\mathrm{h}^{+}$and $\mathrm{O}_{2}^{--}$, but $\mathrm{OH}^{-}$radical has no significant effect in the photodecomposition process.

Acknowledgements The authors would like to thank University of Tehran for financial support of this research.

Open Access This article is distributed under the terms of the Creative Commons Attribution 4.0 International License (http://creativeco mmons.org/licenses/by/4.0/), which permits unrestricted use, distribution, and reproduction in any medium, provided you give appropriate credit to the original author(s) and the source, provide a link to the Creative Commons license, and indicate if changes were made.

Fig. 10 a Schematic representation of TCF nanocomposite formation, and $\mathbf{b}$ suggested reaction mechanism for MB photodecomposition in the presence of TCF under visible light 


\section{References}

1. Kümmerer, K., Dionysiou, D.D., Olsson, O., Fatta-Kassinos, D.: A path to clean water. Science 361(6399), 222-224 (2018). https ://doi.org/10.1126/science.aau2405

2. Buthelezi, S.P., Olaniran, A.O., Pillay, B.: Textile dye removal from wastewater effluents using bioflocculants produced by indigenous bacterial isolates. Molecules 17(12), 14260-14274 (2012). https://doi.org/10.3390/molecules 171214260

3. Yaseen, D.A., Scholz, M.: Treatment of synthetic textile wastewater containing dye mixtures with microcosms. Environ. Sci. Pollut. Res. 25(2), 1980-1997 (2018). https://doi.org/10.1007/ s11356-017-0633-7

4. http://molview.org

5. Attia, A.A., Girgis, B.S., Fathy, N.A.: Removal of methylene blue by carbons derived from peach stones by $\mathrm{H}_{3} \mathrm{PO}_{4}$ activation: batch and column studies. Dyes Pigments 76(1), 282-289 (2008). https ://doi.org/10.1016/j.dyepig.2006.08.039

6. Dewachter, P., Mouton-Faivre, C., Tréchot, P., Lieu, J.C., Mertes, P.M.: Severe anaphylactic shock with methylene blue instillation. Anesth. Analg. 101(1), 149-150 (2005). https://doi. org/10.1213/01.ane.0000153497.60047.80

7. Jadhav, S.V., Bringas, E., Yadav, G.D., Rathod, V.K., Ortiz, I., Marathe, K.V.: Arsenic and fluoride contaminated groundwaters: a review of current technologies for contaminants removal. J. Environ. Manag. 162, 306-325 (2015). https://doi.org/10.1016/j. jenvman.2015.07.020

8. Kabra, K., Chaudhary, R., Sawhney, R.L.: Treatment of hazardous organic and inorganic compounds through aqueous-phase photocatalysis: a review. Ind. Eng. Chem. Res. 43(24), 7683-7696 (2004). https://doi.org/10.1021/ie0498551

9. Young, I.G., Lipták, B.G.: Analytical Instrumentation. Routledge, New York (1994). https://doi.org/10.1201/9781315137469

10. Wang, J.L., Xu, L.J.: Advanced oxidation processes for wastewater treatment: formation of hydroxyl radical and application. Crit. Rev. Environ. Sci. Technol. 42(3), 251-325 (2012). https://doi. org/10.1080/10643389.2010.507698

11. Santhosh, C., Velmurugan, V., Jacob, G., Jeong, S.K., Grace, A.N., Bhatnagar, A.: Role of nanomaterials in water treatment applications: a review. Chem. Eng. J. 306, 1116-1137 (2016). https://doi.org/10.25112/rco.v1i0.1706

12. Delsouz Khaki, M.R., Shafeeyan, M.S., Abdul Raman, A.A., Wan Daud, W.M.A.: Application of doped photocatalysts for organic pollutant degradation - a review. J. Environ. Manag. 198, 78-94 (2017). https://doi.org/10.1016/j.jenvman.2017.04.099

13. Rauf, M.A., Meetani, M.A., Hisaindee, S.: An overview on the photocatalytic degradation of azo dyes in the presence of $\mathrm{TiO}_{2}$ doped with selective transition metals. Desalination 276(1-3), 13-27 (2011). https://doi.org/10.1016/j.desal.2011.03.071

14. Malato, S., Maldonado, M.I., Fernández-Ibáñez, P., Oller, I., Polo, I., Sánchez-Moreno, R.: Decontamination and disinfection of water by solar photocatalysis: the pilot plants of the Plataforma Solar de Almeria. Mater. Sci. Semicond. Process. 42, 15-23 (2016). https://doi.org/10.1016/j.mssp.2015.07.017

15. Hoffmann, M.R., Martin, S.T., Choi, W., Bahnemann, D.W.: Environmental applications of semiconductor photocatalysis. Chem. Rev. 95(1), 69-96 (1995). https://doi.org/10.1021/cr00033a004

16. Yu, S., Lee, B., Lee, M., Cho, I.-H., Chang, S.-W.: Decomposition and mineralization of cefaclor by ionizing radiation: kinetics and effects of the radical scavengers. Chemosphere 71(11), 2106-2112 (2008). https://doi.org/10.1016/j.chemosphere.2008.01.020

17. Ahmad, R., Ahmad, Z., Khan, A.U., Mastoi, N.R., Aslam, M., Kim, J.: Photocatalytic systems as an advanced environmental remediation: recent developments, limitations and new avenues for applications. J. Environ. Chem. Eng. 4(4A), 4143-4164 (2016). https://doi.org/10.1016/j.jece.2016.09.009

18. Chen, X., Mao, S.S.: Titanium dioxide nanomaterials: synthesis, properties, modifications and applications. Chem. Rev. 107(7), 2891-2959 (2007). https://doi.org/10.1021/cr0500535

19. Pelaez, M., Nolan, N.T., Pillai, S.C., Seery, M.K., Falaras, P., Kontos, A.G., Dunlop, P.S.M., Hamilton, K.W.J., Byrne, J.A., O'Shea, K., Entezari, M.H., Dionysiou, D.D.: A review on the visible light active titanium dioxide photocatalysts for environmental applications. Appl. Catal. B Environ. 125, 331-349 (2012). https://doi.org/10.1016/j.apcatb.2012.05.036

20. Nakata, K., Ochiai, T., Murakami, T., Fujishima, A.: Photoenergy conversion with $\mathrm{TiO}_{2}$ photocatalysis: new materials and recent applications. Electrochim. Acta 84, 103-111 (2012). https://doi.org/10.1016/j.electacta.2012.03.035

21. Wu, L., Mendoza-garcia, A., Li, Q., Sun, S.: Organic phase syntheses of magnetic nanoparticles and their applications. Chem. Rev. 116, 10473-10512 (2016). https://doi.org/10.1021/acs. chemrev.5b00687

22. Huang, Y., Keller, A.A.: EDTA functionalized magnetic nanoparticle sorbents for cadmium and lead contaminated water treatment. Water Res. 80, 159-168 (2015). https://doi. org/10.1016/j.watres.2015.05.011

23. Baker, D.R., Kamat, P.V.: Photosensitization of $\mathrm{TiO}_{2}$ nanostructures with CdS quantum dots: particulate versus tubular support architectures. Adv. Funct. Mater. 19(5), 805-811 (2009). https ://doi.org/10.1002/adfm.200801173

24. Suwarnkar, M.B., Dhabbe, R.S., Kadam, A.N., Garadkar, K.M.: Enhanced photocatalytic activity of Ag doped $\mathrm{TiO}_{2}$ nanoparticles synthesized by a microwave assisted method. Ceram. Int. 40(4), 5489-5496 (2014). https://doi.org/10.1016/j.ceram int.2013.10.137

25. Gómez-Pastora, J., Dominguez, S., Bringas, E., Rivero, M.J., Ortiz, I., Dionysiou, D.D.: Review and perspectives on the use of magnetic nanophotocatalysts (MNPCs) in water treatment. Chem. Eng. J. 310, 407-427 (2017). https://doi.org/10.1016/j. cej.2016.04.140

26. Dionysiou, D., Puma, G.L., Ye, J., Schneider, J., Bahnemann, D.: Photocatalysis Fundamentals and Perspectives. The Royal Society of Chemistry (RSC), Cambridge (2016). https://doi. org/10.1039/9781782622338

27. Reddy, D.H.K., Yun, Y.S.: Spinel ferrite magnetic adsorbents: alternative future materials for water purification? Coord. Chem. Rev. 315, 90-111 (2016). https://doi.org/10.1016/j. ccr.2016.01.012

28. Selima, S.S., Khairy, M., Mousa, M.A.: Comparative studies on the impact of synthesis methods on structural, optical, magnetic and catalytic properties of $\mathrm{CuFe}_{2} \mathrm{O}_{4}$. Ceram. Int. 45(5), 65356540 (2019). https://doi.org/10.1016/j.ceramint.2018.12.146

29. Sabbaghan, M., Sofalgar, P.: Single-phase $\gamma-\mathrm{Fe}_{2} \mathrm{O}_{3}$ nanoparticles synthesized by green ionothermal method and their magnetic characterization. Ceram. Int. 42(15), 16813-168163 (2016). https://doi.org/10.1016/j.ceramint.2016.07.172

30. Zhang, X., Lei, L.: Preparation of photocatalytic $\mathrm{Fe}_{2} \mathrm{O}_{3}-\mathrm{TiO}_{2}$ coatings in one step by metalorganic chemical vapor deposition. Appl. Surf. Sci. 254, 2406-2412 (2008). https://doi. org/10.1016/j.apsusc.2007.09.067

31. Yi, D.K., Lee, S.S., Ying, J.Y.: Synthesis and applications of magnetic nanocomposite catalysts. Chem. Mater. 18(10), 24592461 (2006). https://doi.org/10.1021/cm052885p

32. Mitra, A., Vázquez, C.V., López-Quintela, M.A., Paul, B.K., Bhaumik, A.: Soft-templating approach for the synthesis of high surface areaand superparamagnetic mesoporous iron oxide materials. Microporous Mesoporous Mater. 131(1-3), 373-377 (2010). https://doi.org/10.1016/j.micromeso.2010.01.017 
33. Arifin, M.N., Rezaul Karim, K.M., Abdullah, H., Khan, M.R.: Synthesis of titania doped copper ferrite photocatalyst and its photoactivity towards methylene blue degradation under visible light irradiation. Bull. Chem. React. Eng. Catal. 14(1), 219-227 (2019). https://doi.org/10.9767/bcrec.14.1.3616.219-227

34. Khan, M.R., Uddin, M.R., Abdullah, H., Karim, K.R., Yousuf, A.: Preparation and characterization of $\mathrm{CuFe}_{2} \mathrm{O}_{4} / \mathrm{TiO}_{2}$ photocatalyst for the conversion of $\mathrm{CO}_{2}$ into methanol under visible light. Int. Sch. Sci. Res. Innov. 10(10), 1273-1280 (2016)

35. Kezzim, A., Nasrallah, N., Abdi, A., Trari, M.: Visible light induced hydrogen on the novel hetero-system $\mathrm{CuFe}_{2} \mathrm{O}_{4} / \mathrm{TiO}_{2}$. Energy Convers. Manag. 52, 2800-2806 (2011). https://doi. org/10.1016/j.enconman.2011.02.014

36. Yusuf, H.Y., Kumar Lakhera, S., Karthik, P., Anpo, M., Neppolian, B.: Facile construction of ternary $\mathrm{CuFe}_{2} \mathrm{O}_{4}-\mathrm{TiO}_{2}$ nanocomposite supported reduced graphene oxide $(\mathrm{rGO})$ photocatalysts for the efficient hydrogen production. Appl. Surf. Sci. 449, 772-779 (2018). https://doi.org/10.1016/j.apsusc.2018.01.282

37. Ebrahimian Pirbazari, A., Monazzam, P., Fakhari Kisomi, B.: Co/ $\mathrm{TiO}_{2}$ nanoparticles: preparation, characterization and its application for photocatalytic degradation of methylene blue. Desalin. Water Treat. 63, 283-292 (2017). https://doi.org/10.5004/ dwt.2017.20205

38. Hashemian, S., Ardakani, M.K., Salehifar, H.: Kinetics and thermodynamics of adsorption methylene blue onto tea waste/ $\mathrm{CuFe}_{2} \mathrm{O}_{4}$ composite. Am. J. Anal. Chem. 4(7), 1-7 (2013). https ://doi.org/10.4236/ajac.2013.47A001

39. Thapa, D., Kulkarni, N., Mishra, S.N., Paulose, P.L., Ayyub, P.: Enhanced magnetization in cubic ferrimagnetic $\mathrm{CuFe}_{2} \mathrm{O}_{4}$ nanoparticles synthesized from a citrate precursor: the role of $\mathrm{Fe}^{2+}$. J. Phys. D Appl. Phys. 43(19), 195004 (2010). https://doi. org/10.1088/0022-3727/43/19/195004

40. Suresh, S., Karthikeyan, S., Jayamoorthy, K.: Effect of bulk and nano- $\mathrm{Fe}_{2} \mathrm{O}_{3}$ particles on peanut plant leaves studied by Fourier transform infrared spectral studies Effect of $\mathrm{Fe}_{2} \mathrm{O}_{3}$ particles on peanut plant leaves. J. Adv. Res. 7(5), 739-747 (2016). https:// doi.org/10.1016/j.jare.2015.10.002

41. Wu, H., Wu, G., Wang, L.: Peculiar porous $\alpha-\mathrm{Fe}_{2} \mathrm{O}_{3}, \gamma-\mathrm{Fe}_{2} \mathrm{O}_{3}$ and $\mathrm{Fe}_{3} \mathrm{O}_{4}$ nanospheres: facile synthesis and electromagnetic properties. Powder Technol. 269, 443-451 (2015). https://doi. org/10.1016/j.powtec.2014.09.045

42. Tronc, E., Chane, C., Jolivet, J.P.: Structural and magnetic characterization of e- $\mathrm{Fe}_{2} \mathrm{O}_{3}$. J. Solid State Chem. 139(1), 93-104 (1998). https://doi.org/10.1006/jssc.1998.7817

43. Ogata, M., et al.: Effect of aliovalent dopants on the kinetics of spinodal decomposition in rutile-type $\mathrm{TiO}_{2}-\mathrm{VO}_{2}$. J. Eur. Ceram. Soc. 37(9), 3177-3183 (2017). https://doi.org/10.1016/j.jeurc eramsoc.2017.03.039

44. Scherrer, P.: Determination of the internal structure and size of colloid particles by X-rays. Mathematisch-Physikalische Klasse Gottingen 2, 98-100 (1918)

45. Khan, M., Cao, W.: Cationic (V, Y)-codoped $\mathrm{TiO}_{2}$ with enhanced visible light induced photocatalytic activity: A combined experimental and theoretical study. J. Appl. Phys. 114(18), 183514 (2013)

46. Ashcroft, N.W., Mermin, N.D.: Solid State Physics. Saunders College, Philadelphia (1976)

47. Venkatachalam, N., Palanichamy, M., Arabindoo, B., Murugesan, V.: Enhanced photocatalytic degradation of 4-chlorophenol by $\mathrm{Zr}^{4+}$ doped nano $\mathrm{TiO}_{2}$. J. Mol. Catal. A: Chem. 266(1-2), 158-165 (2007). https://doi.org/10.1016/j.molcata.2006.10.051

48. Ghasemi, S., Rahimnejad, S., Rahman Setayesh, S., Rohani, S., Gholami, M.R.: Transition metal ions effect on the properties and photocatalytic activity of nanocrystalline $\mathrm{TiO}_{2}$ prepared in an ionic liquid. J. Hazard. Mater. 172(2-3), 1573-1578 (2009). https://doi.org/10.1016/j.jhazmat.2009.08.029

49. Venkatachalam, N., Palanichamy, M., Murugesan, V.: Sol-gel preparation and characterization of alkaline earth metal doped nano $\mathrm{TiO}_{2}$ : efficient photocatalytic degradation of 4-chlorophenol. J. Mol. Catal. A Chem. 273(1-2), 177-185 (2007). https://doi. org/10.1016/j.molcata.2007.03.077

50. Rahman, S.S.U., Qureshi, M.T., Sultana, K., Rehman, W., Khan, M.Y., Asif, M.H., Farooq, M., Sultana, N.: Single step growth of iron oxide nanoparticles and their use as glucose biosensor. Results Phys. 7, 4451-4456 (2017). https://doi.org/10.1016/j. rinp.2017.11.001

51. Kumar, S., Khanchandani, S., Thirumal, M., Ganguli, A.K.: Achieving enhanced visible-light-driven photocatalysis using type-II $\mathrm{NaNbO}_{3} / \mathrm{CdS}$ core/shell heterostructures. ACS Appl. Mater. Interfaces 6(15), 13221-13233 (2014). https://doi. org/10.1021/am503055n

52. Rouquerol, J., Anvir, D., Fairbridge, C.W., Everett, D.H., Haynes, J.H., Pernicone, N., Ramsay, J.D.F., Sing, K.S.W., Unger, K.K.: Recommendation for the characterization of porous solids. Pure Appl. Chem. 66(8), 1739-1758 (1994)

53. Zdravkov, B.D., Cermak, J.J., Sefara, M., Janku, J.: Pore classification in the characterization of porous materials: a perspective. Cent. Eur. J. Chem. 5(2), 385-395 (2007). https://doi.org/10.2478/ s11532-007-0017-9

54. Ng, K.H., Cheng, C.K.: Photo-polishing of POME into $\mathrm{CH}_{4}$-lean biogas over the UV-responsive $\mathrm{ZnO}$ photocatalyst. Chem. Eng. J. 300, 127-138 (2016). https://doi.org/10.1016/j.cej.2016.04.105

55. Anuchai, S., Phanichphant, S., Tantraviwat, D., Pluengphon, P., Bovornratanaraks, T., Inceesungvorn, B.: Low temperature preparation of oxygen-deficient tin dioxide nanocrystals and a role of oxygen vacancy in photocatalytic activity improvement. J. Colloid Interface Sci. 512, 105-114 (2018). https://doi.org/10.1016/j. jcis.2017.10.047

Publisher's Note Springer Nature remains neutral with regard to jurisdictional claims in published maps and institutional affiliations. 